\title{
Roles of Regulation and Lifestyle on Indonesian Coffee Consumption Behavior Across Generations
}

\author{
Adi Prasetya Utama ${ }^{1 *}$, Ujang Sumarwan ${ }^{2}$, Arif Imam Suroso ${ }^{1}$, Mukhamad Najib ${ }^{1}$ \\ ${ }^{1}$ School of Business, IPB University, Bogor 16151, Indonesia \\ ${ }^{2}$ Department of Family and Consumer Sciences, Faculty of Human Ecology, IPB University, Bogor 16151, Indonesia
}

Corresponding Author Email: prasetya_dmb12@apps.ipb.ac.id

https://doi.org/10.18280/ijsdp.160616

Received: 12 August 2021

Accepted: 10 October 2021

Keywords:

lifestyle, consumer behavior, SOR, AISAS

\begin{abstract}
Coffee beverage consumption has become more important in the recent years and has touched the lifestyles of the old and young people. The research of coffee consumption, especially in relation to the lifestyles of the people, therefore needs to be intensified. The purpose of this study was to compare the contribution of regulation and lifestyle in determining coffee drink consumption among old and young consumers. The theory adopted was the SOR (stimulusorganism-response) theory and the AISAS (attention-interest-search-action-share) model approach. Data were collected online in April-May 2020, and obtained 413 valid respondent data, which consist of 207 old respondents and 206 young respondents. The results showed that the lifestyle variable had positive effects on attitude and search behavior of both young and old generations. The lifestyle variable also had significant effects on coffee consumption for both generations. The regulation variable had positive effects on attitude and action of young coffee consumers, but it had no effect on attitude, search and action of old consumers. The research suggests that, to increase coffee consumption, better regulation approach should consider the age of the consumer. Especially, more attention should be paid for the regulation on coffee marketing for older generation.
\end{abstract}

\section{INTRODUCTION}

World coffee consumption has been reported increasing in the last few years. International Coffee Organization [1], reported the growth of world coffee consumption with the rate of about $1.1 \%$ per year. However, in spite of the positive increase in coffee consumption, the gap of per capita consumption between developed and developing countries is still relatively high. In 2020 coffee consumption per capita in developed countries was relatively high, including Norway $10.3 \mathrm{~kg}$ /year, Switzerland $7.4 \mathrm{~kg} /$ year, European Union 5.9 $\mathrm{kg} /$ year, USA $4.9 \mathrm{~kg} /$ year, Brazil $5.0 \mathrm{~kg} / \mathrm{year}$, while consumption of coffee drinks in many developing countries was relatively low, namely, Indonesia only $1.4 \mathrm{~kg} /$ year, Vietnam $1.7 \mathrm{~kg} /$ year, the Philippines $1.8 \mathrm{~kg} /$ year, Thailand 1.3 $\mathrm{kg} /$ year [1].

In Indonesia, amid the euphoria of cafe development, coffee consumption growth per capita in fact is relatively not very high in the last five years; i.e. $\pm 2 \%$ per year in average. According to local Central Bureau of Statistics, the growth of coffee consumption per capita in consecutive years are as follows: 2016 was $1.55 \mathrm{~kg}, 2017$ was $1.67 \mathrm{~kg}, 2018$ was 1.73 $\mathrm{kg}, 2019$ was $1.70 \mathrm{~kg}$ and 2020 was $1.70 \mathrm{~kg}$ [2-6]. Given this large gap between developed countries and developing countries, especially for Indonesia, it is possible to increase coffee consumption per capita in the near future.

There are many factors determining the level of coffee consumption. Samoggia and Riedel [7] grouped several determinants of coffee consumption, including (1) personal preferences, (2) economic attributes, (3) product attributes, (4) context of consumption, and (5) socio-demographics. Moreover they also noted that scientific knowledge of the motives and characteristics of coffee consumption is actually incomplete due to research that often focused on a limited number of issues. Therefore more researches regarding the motive and characteristics of coffee consumption are certainly still needed.

Sumarwan [8] further explained that consumer consumption decisions are largely determined by; (1) marketing strategies by producers and the government, (2) differences in individual characteristics, and (3) environmental factors. This statement confirms that the government has an important role in determining consumer consumption decisions.

Several theories and approaches have been considered by researchers to analyze coffee drinking behavior. This study tries to adopt the theory of SOR (Stimulus, Organism, Response) $[9,10]$. The theory that was initially proposed by Mehrabian and Russell describes how people react to stimuli in the environment [11]. The theory of S-O-R (Stimulus Organism Response) was proposed because of the influence of psychology in communication science. The S-O-R framework theory arose because psychology and communication basically have the same object of study, namely the human soul; which includes attitudes, opinions, behavior, cognition, affection and conation. The basic assumption of S-O-R theory is that the causes of behavior change depend on the quality of the stimuli that communicate with the organism.

The theory suggested that the stimulus will affect the organism and the organism will affect the response [11]. Chen et al. [12] said that based on the SOR model, consumer 
behaviors are affected by stimulus, which comes from consumer physical, psychological and external environment. Affected by stimulus, consumers may produce some motivation or attitude, which causes consumer buying decision-making.

The later research revealed that the stimulus not only directly affects the organism but it can also directly affect the response [13-16]. The model indicates that the created environment (S-Stimulus) can influence the customer's mood (O-Organism), which generates a behavioral response (RResponse). The SOR model has been widely used to explain consumer loyalty, purchase intention, buying behavior, engagement, co-creation and so on [17].

Over the last few years, many researches have paid attention to consumer behaviors related to electronic transactions. The SOR model, even though can be adopted to analyze the online business processes, basically are based on traditional marketing framework AIDMA (Attention, Interest, Demand, Memory, Action) [12]. The responses that have been measured using the SOR framework in the last few years are such as online purchase intention [18, 19], impulsive buying [20], online repurchase intention [19], purchase completion intention [21], environmental word of mouth intention for organic foods [22].

Due to the importance of the response of electronic transactions, it is important to consider other framework that is based on electronic system to the SOR model. The AISAS model emerged along with the development of internet technology in marketing communication. This model explained the situation when in need of high-involvement goods, customers will do a deeper search than when need of low-involvement stuff. Based on this phenomenon, Dentsu analized the situation and proposed a marketing communication model, which was then named the AISAS model [23].

Chen et al. [12] proposed two keys of the later system, they are to search information easily and more importantly are to accelerate the spreading speed of desirable buying experiences (sharing). Those last responses are included in AISAS (Awareness, Interest, Search, Action and Share) approach. Moreover in order to check the direct and total influences of the stimulus on organism and consumer response, the SOR then further developed by adopting the AISAS framework.

The purpose of this study is to measure and to compare the significance and contribution of regulation factor together with lifestyle factor, in determining the level of coffee drink consumption across generation. The research is important to explore the appropriate government intervention regarding coffee consumption, especially for young and older generation. Furthermore, based on the findings of the research, the implications of the appropriate coffee beverage marketing regulation could be compiled.

\section{LITERATURE REVIEW}

\subsection{Consumption of coffee beverages}

\subsubsection{Coffee drinking measure}

Influences of various factors on coffee drinking behavior have been measured in previous studies. Coffee consumption are defined as: the habit of drinking coffee [24], intention (interest) to drink coffee [25-30], interest in reconsuming/buying coffee (revisit/repurchase intention) [31-
33], frequency of drinking coffee [34], coffee drinking culture [34], coffee drinking satisfaction [27, 30, 35], coffee drinking loyalty [36], and the quality of the drinking experience coffee (experiential quality) [37].

Aguirre [34] found that the important factors determining the consumption of coffee drinks, are: gender, family as a source of information, health, amount spent, aroma, antimigraine effect, family traditions, taste, and energy effects. He then proposed in his research, coffee drink consumption behavior was measured by the frequency of drinking coffee in one day, namely, by the category of 1-2 cups a day, 3-4 cups a day, 5-6 cups a day, and over 6 cups a day. His research showed that the average Costa Rican 23\% drank 1-2 cups, $41 \%$ drank 3-4 cups and 36\% drank 5-6 cups, and none of them drank more than 6 cups. His research confirms that gender, health, and cultural factors are significant predictors of coffee consumption levels in Costa Rica.

\subsubsection{Regulation}

Sumarwan [8] explained the influence of government policies and strategies on consumer consumption decisions. In domestic consumer consumption, policies and programs to increase domestic coffee consumption are very important, especially for coffee producing countries [38]. Kanniah [39] explained several benefits of programs to increase domestic consumption, rather than encouraging exports, including: (1) increasing domestic overall demand, (2) reducing logistics transportation risks, (3) avoiding the risk of fluctuating exchange rates, (4) more profits are obtained because the industrial chain to consumption is shorter, (5) avoids competition with sources from other countries. Kanniah [39] further described several countries that have succeeded in encouraging domestic consumption, including Brazil, Columbia and Guatemala, through several campaigns and promotion programs

Domestically, in Indonesia, the Government has pushed various policies to increase the coffee trade. However, Andoko et al. [40] illustrated that at the site level, there are differences in perceptions captured by business people, including understanding that the central government is not serious in handling various issues regarding coffee productivity and various issues regarding the sustainability of coffee production. This fact shows that producers and consumers in the field may feel differently from what policy makers intended. In the context of consumer behavior, measurement of consumer perceptions is necessary to know the reality that consumers feel.

Based on the review above, some hypotheses regarding regulation variable could be developed, they are:

H1: Regulation has a positive effect on Attitude

H2: Regulation has a positive effect on Search

H3: Regulation has a positive effect on Action

\subsubsection{Lifestyle}

Lifestyle is one of the important factors influencing a person's consumer behavior. There are many researches examining the influences of lifestyle factors to food/beverage consumer behavior [41-44]. Basha et al. [41] and Najib et al. [45] showed that lifestyle is one of one's motives for consuming organic products. An environmentally friendly lifestyle significantly influences the intention to buy organic products.

Some researchers $[24,26]$ have studied lifestyle as one variable of coffee consumption. The research results are 
generally in line with the results of other researches regarding food consumption, that lifestyle variables have a significant effect on coffee drinking behavior. Chairy [26] showed that a lifestyle with spirituality affects a person's intention to drink coffee. Lifestyle here is related to how a person lives, namely his activities, interests, likes, attitudes, consumption, expectations and feelings.

The relationships between consumption behavior and purchasing decision making behavior for canned coffee have been observed by some researchers [46]. They revealed that (a) different lifestyles have a significant effect on the amount of consumption and purchasing decision making; (b) different consumption motives have a significant effect on the amount of consumption and the level of preference for usage behavior and purchasing decision making. Zahra and Anoraga [47] also show that there is a positive relationship between lifestyle and consumptive behavior patterns of students towards goods that are less needed.

Based on the analysis above, the influence of lifestyle to the consumer behavior can be predicted. Some hypotheses about lifestyle as an independent variable could then be developed, they are:

H4: Lifestyle has a positive effect on Attitude

H5: Lifestyle has a positive effect on Search

H6: Lifestyle has a positive effect on Action

\subsection{Generation and coffee consumption}

There are some definitions of generations that have been proposed, namely Baby Boomers, Generation Xers, Generation Y/Millenial, and Post Millenials [48, 49]. For the purpose of this research, the definition is described as follows: Silent (Born 1928-1945), Boomers (Born 1946-1964), Generation X (Born 1965-1980), Millenials (Born 1981-1994) and Generation Z (Born 1995-2010).

Some researchers stated that there could be relationships between generation (age) and certain food/drink consumptions [24, 50, 51]. Hewlett and Wadsworth [24] stated that coffee and tea drinking patterns are largely determined by demographic factors, health and lifestyle considerations. Their research revealed that there could be association between age and coffee consumption behavior.

Howe and Strauss [52] stated that Millennials are often defined by their preoccupation with instant information transfer. Furthermore, food plays an important role in the social interactions of Millennial consumers where they can spend their money on recreation which includes eating as opposed to other experiences. This is supported by Harris et al [53], which showed that millennials spend a lot of their money on fast food compared to other commodities. Solomon [54] showed the relationship between millennial socialization, entertainment and consumption patterns, related to their interest in fun; and their high spending ability built on the idea that Millennials live for the moment and believe in enjoying themselves.

Segokgo [55] in a study of millennials found that the level of knowledge affects the food consumption decisions of millennials. Millennials with low levels of nutritional knowledge are more likely to be influenced by fast food advertisements. Chairy [26] shows that spirituality and lifestyle positively and significantly affect the intention to consume organic coffee among millennials.

Falkner [51] also showed that there is association between age and coffee consumption. Based on his own research, he concluded that differences exist between the coffee preferences across all generations, especially when it comes to the current trends (e.g., premiumization, convenience, and sustainability).

The previous findings showed that the association between coffee consumption and consumer age clearly existed. However the form of association could be different in certain respondents and commodity. Moreover the behavior of old consumers could be different from the one of young consumer. The research that focused on behavior across generations, therefore could reveal some insight and practical recommendation.

\subsection{AISAS model}

Recent developments in the internet technology and product marketing provide an even stronger impetus to explore suitable models. The AISAS model is considered to be more relevant to the latest development since consumer behavior now has been more influenced by internet compared to the previous era. Sugiyama and Andree [23] explain that this change in behavior patterns is driven by the rapid development of internet technology so as to create a digital or online era. The communication strategy is directed at creating scenarios that direct consumers to voluntarily seek information about products, buy products, and then spread positive word-ofmouth to other consumers.

Some researchers have been carried out adopting AISAS model. Abdurrahim et al. [56] confirmed that the AISAS model can be used to analyze the effect of tourism destination in social media to the customers. Iskandar et al. [57] measured and proved the effects of AISAS variables to the Sharia Banking Literacy. Utama et al. [58] adopted the AISAS principle to measure effects of some parameters to coffee consumption behavior. Moreover, in the context digital consumers, research conducted by Najib and Fahma [59] demonstrated that attitude positively influenced consumer's action.

Furthermore, as described by Sugiyama and Andree [23], it can be seen that the Attention and Interest (AI) variables are actually a single psychological process. In this research they are classified as Attitude. This is different from the Search, Action and Share (SAS) variables, which are more of a behavioral process as a result of the AI process.

Based on the review above, some hypotheses regarding the interactions among Attitude, Search, Action and Share could be proposed as follows:

H7: Attitude has a positive effect on Search

H8: Attitude has a positive effect on Action

H9: Search has a positive effect on Action

H10: Action has a positive effect on Share

\subsection{Research model}

In this study, the principles of SOR (Stimulus, Organism, and Response) were adopted. The variables of Regulation and Lifestyles were included as stimuli, Attitude was included in the organism, and response were consisted of Search, Action and Share. It was expected that Regulation factor would directly affect Attitude, Search and Action of the coffee consumers. It was also expected that Lifestyle would directly affect Attitude, Search and Action of the coffee consumers. In this last principle, factors of Awareness and Interest were combined into a single factor of Attitude. The last parameter 
of the model was Share.

The research design was described in Figure 1 as follows:

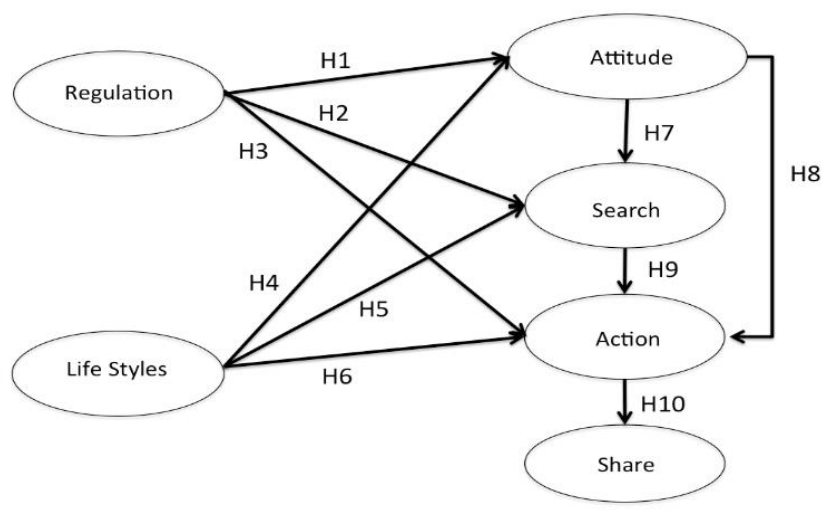

Figure 1. Coffee consumption research model

\section{RESEARCH METHOD}

\subsection{Location and time of research}

Data collection was conducted through an online survey in April-May 2020. The research was carried out in the territory of Indonesia, especially on the island of Java, which is the most populous area in Indonesia. Questionnaires were distributed online to the respondents in person and through social media that could be accessed by the public, including Facebook, Instagram, WhatsApp, and Telegram.

\subsection{Sampling method}

The respondents were chosen based on convenience sampling method, which is part of the non-probability sampling. Every consumer who meets the population criteria does not have the same opportunity to be selected as a sample because the sample selection is based on the researcher's decision [60]. Convenience sampling is a data collection technique based on certain research criteria. Convenience sampling is also used because the exact population size is unknown [61]. The criteria for respondents in this study are consumers who were used to drinking coffee at least once a week. Samples collected in this study were 420 . However, after cleaning process, there are 413 samples that can be continued to the analysis process. The data was then stratified into two groups, namely old generation group (BX generation) which consists of 207 people, and young generation group (YZ generation) which consists of 206 people.

\subsection{Variables and indicators}

There are six latent variables used in this study, namely, Regulation (REG), Lifestyle (LS), Attitude (AT), Search (SE), Action (AC) and Share (SH). Regulation and Lifestyle variables are exogenous variables, while the variables of Attitude, Interest, Search, Action and Share are endogenous variables. The description of the variables and indicators can be seen in Table 1 .

\subsection{Data processing}

Data were processed using Structural Equation Modeling (SEM) framework and LISREL 8.80 applications. SEM analysis involves both the test of a measurement theory and the structural theory that links constructs together in a logically meaningful way. Moreover, SEM is used because it can be used to measure and analyze the relationships of observed and latent variables [62]. Whereas LISREL is adopted because this application can be used for standard and multilevel structural equation modeling. These methods are available for the complete and incomplete complex survey data on categorical and continuous variables [63].

Table 1. Variables and indicators of the model

\begin{tabular}{|c|c|c|c|c|c|}
\hline Num & Variable & Operational Definition & Code & Indicator & Reference \\
\hline \multirow{4}{*}{1} & \multirow{4}{*}{$\begin{array}{l}\text { Government } \\
\text { Regulation }\end{array}$} & \multirow{4}{*}{$\begin{array}{c}\text { Various Government } \\
\text { policies/programs related to coffee } \\
\text { consumption }\end{array}$} & $\mathrm{REG}_{1}$ & Appreciation for Gov. policies. & \multirow{4}{*}[64]{} \\
\hline & & & $\mathrm{REG}_{2}$ & Follow Gov. recommendation & \\
\hline & & & $\mathrm{REG}_{3}$ & Education to the community & \\
\hline & & & $\mathrm{REG}_{4}$ & Various Government programs & \\
\hline \multirow{5}{*}{2} & \multirow{5}{*}{ Lifestyle } & \multirow{5}{*}{$\begin{array}{l}\text { Expression of how a person lives, } \\
\text { and activates his self-concept, whict } \\
\text { is determined by past experiences, } \\
\text { internal characteristics, and current } \\
\text { conditions. }\end{array}$} & $\mathrm{LS}_{1}$ & Always try to consume & \multirow{5}{*}[26,63,65]{} \\
\hline & & & $\mathrm{LS}_{2}$ & Invite others to drink & \\
\hline & & & $\mathrm{LS}_{3}$ & Try to have supplies & \\
\hline & & & $\mathrm{LS}_{4}$ & Keep trying to drink & \\
\hline & & & $\mathrm{LS}_{5}$ & Always follow developments & \\
\hline \multirow{5}{*}{3} & \multirow{5}{*}{ Attitude } & \multirow{5}{*}{$\begin{array}{l}\text { Evaluation, emotional feeling, and } \\
\text { tendency to act from someone } \\
\text { who likes or dislikes an object. }\end{array}$} & $\mathrm{AT}_{1}$ & Preference level & \multirow{5}{*}{ [66] } \\
\hline & & & $\mathrm{AT}_{2}$ & Satisfaction level & \\
\hline & & & $\mathrm{AT}_{3}$ & Feelings for coffee & \\
\hline & & & $\mathrm{AT}_{4}$ & Love for taste & \\
\hline & & & $\mathrm{AT}_{5}$ & Feel loyal & \\
\hline \multirow{4}{*}{4.} & \multirow{4}{*}{ Search } & \multirow{4}{*}{$\begin{array}{l}\text { Efforts from consumers to find } \\
\text { more information from the } \\
\text { internet about coffee }\end{array}$} & $\mathrm{SE}_{1}$ & Searching more information & \multirow{4}{*}[23,56]{} \\
\hline & & & $\mathrm{SE}_{2}$ & Searching through social media & \\
\hline & & & $\mathrm{SE}_{3}$ & Make use of search engines & \\
\hline & & & $\mathrm{SE}_{4}$ & Searching by asking other people & \\
\hline \multirow{3}{*}{5.} & \multirow{3}{*}{ Action } & \multirow{3}{*}{$\begin{array}{l}\text { Purchase / consumption activities } \\
\text { carried out by coffee consumers. }\end{array}$} & $\mathrm{AC}_{2}$ & Consumption due to promotion & \multirow{3}{*}[23,56]{} \\
\hline & & & $\mathrm{AC}_{3}$ & Drink coffee because of the taste & \\
\hline & & & $\mathrm{AC}_{6}$ & Action Because the purchase is easy & \\
\hline \multirow{4}{*}{6.} & \multirow{4}{*}{ Share } & \multirow{4}{*}{$\begin{array}{l}\text { The activity of sharing coffee } \\
\text { drinking experiences on social } \\
\text { media / internet. }\end{array}$} & $\mathrm{SH}_{1}$ & Share because it meets expectations & \multirow{4}{*}[23,56]{} \\
\hline & & & $\mathrm{SH}_{2}$ & Share because hope friends will find & \\
\hline & & & $\mathrm{SH}_{3}$ & Share because it does not match expect & \\
\hline & & & $\mathrm{SH}_{4}$ & Share via personal social media & \\
\hline
\end{tabular}




\subsection{Results}

Based on the respondent profile data (Table 2), from a total of 413 respondents, 299 people (72\%) were men, while 114 others $(28 \%)$ were women. In addition, it is important to convey the age composition of respondents consisting of young respondents, namely, the Generation $Z$ (born between 1995-2010), as many as 104 people (25\%), and the Millennial Generation Y (born between 1980-1994), as many as 102 people $(25 \%)$. While the older/mature generation consists of the Baby Boomers generation born between 1946-1964, as many as 27 people (6\%), and the Generation X born between $1965-1979$, as many as 180 people (44\% of the respondents). With a composition of 50-50 between the younger generation and the mature generation, it can be said that this research reaches proportionally in all generations. It is also important to mention that all respondents are coffee drinkers, as shown in Table 2.

The Goodness of Fit (GOF) test of the model (Table 3) shows that in general the models are good and acceptable in describing the interactions between variables in the model. Furthermore, the calculation of the reliability of the models, as can be seen in Table 4, result in Construct Reliability of 0.97 and Variance Extracted of 0.57 for BX generation model; and Construct Reliability of 0.96 and Variance Extracted of 0.50 for YZ generations. According to Hair et al. [62], the minimum standard of $\mathrm{CR}$ is 0.7 and VE is 0.5 . Although for the exploratory test the minimum standard of 0.6 and $\mathrm{VE}$ of at least 0.4 is still acceptable [67].

Table 5 shows the outputs of the LISREL8.8 application, which shows the t-value of each variable in the model and its interaction with other variables. Based on the t-count test, it was found that of the 20 proposed hypotheses, twelve hypotheses could be accepted and eight hypotheses were rejected.

Table 2. Profile of respondents

\begin{tabular}{|c|c|c|c|c|}
\hline No & Dimension & Class & Sum & $\%$ \\
\hline \multirow[t]{2}{*}{1.} & Gender & Men & 299 & 72 \\
\hline & & Women & 114 & 28 \\
\hline \multirow[t]{4}{*}{2.} & Generation & Baby boomers & 27 & 6 \\
\hline & & Gen. X & 180 & 44 \\
\hline & & Gen. Y - Millennial & 102 & 25 \\
\hline & & Gen. Z & 104 & 25 \\
\hline \multirow[t]{4}{*}{3.} & Education & High School & 74 & 18 \\
\hline & & Diploma & 29 & 7 \\
\hline & & Bachelor & 205 & 50 \\
\hline & & Post Graduate & 105 & 25 \\
\hline \multirow[t]{5}{*}{4.} & Job & Private Employee & 78 & 19 \\
\hline & & Entrepreneur & 32 & 8 \\
\hline & & Civil Servant & 187 & 45 \\
\hline & & Student & 72 & 17 \\
\hline & & Other & 44 & 11 \\
\hline \multirow[t]{6}{*}{5.} & Drink Frequency & Uncertain & 75 & 18 \\
\hline & & $1-3$ times a week & 72 & 17 \\
\hline & & Once a day & 102 & 25 \\
\hline & & Twice a day & 105 & 25 \\
\hline & & Three times a day & 27 & 7 \\
\hline & & $>3$ times a day & 32 & 8 \\
\hline
\end{tabular}

Of the BX generation cluster, five hypotheses are accepted, they are $\mathrm{H} 4$ (Lifestyle has a positive effect on Attitude), H5 (Lifestyle has a positive effect on Search), H6 (Lifestyle has a positive effect on Action), H9 (Search has a positive effect on Action), H10 (Action has a positive effect on Share). Five other hypotheses of the BX generation cluster were rejected, they are H1 (Regulation has a positive effect on Attitude), H2 (Regulation has a positive effect on Search), H3 (Regulation has a positive effect on Action), H7 (Attitude has a positive effect on Search) H8 (Attitude has a positive effect on Action).

Table 3. Analysis of the suitability (goodness of fit test) of the overall models

\begin{tabular}{cccccc}
\hline \multirow{2}{*}{ GOF } & \multirow{2}{*}{ Cut off Value } & \multicolumn{2}{c}{ BX Generation } & \multicolumn{2}{c}{ YZ Generation } \\
\cline { 2 - 6 } & & Result & Note & Result & Note \\
\hline Chi -square $\left(\chi^{2}\right)$ & It should be a small value & 487.10 & & 353.88 & \\
\hline Df & & 239 & & 241 & \\
\hline$\left(\chi^{2}\right) / \mathrm{df}$ & $\leq 3 ; 2: 1[68], 3: 1[69]$ & 2.04 & Good fit & 1.47 & Good fit \\
\hline RMR & RMR $\leq 0.05[68]$, or $0.08[62]$ & 0.065 & Good fit & 0.058 & Good fit \\
\hline RMSEA & $\leq 0.08$ & 0.071 & Good fit & 0.047 & Good fit \\
\hline GFI & $\geq 0.90$ & 0.84 & Marginal Fit & 0.88 & Marginal Fit \\
\hline AGFI & $\geq 0.90$ & 0.78 & Marginal Fit & 0.84 & Marginal Fit \\
\hline CFI & $\geq 0.90$ & 0.98 & Good fit & 0.99 & Good fit \\
\hline NFI & $\geq 0.90$ & 0.96 & Good fit & 0.96 & Good fit \\
\hline NNFI & $\geq 0.90$ & 0.98 & Good fit & 0.98 & Good fit \\
\hline RFI & $\geq 0.90$ & 0.95 & Good fit & 0.95 & Good fit \\
\hline IFI & $\geq 0.90$ & 0.98 & Good fit & 0.99 & Good fit \\
\hline
\end{tabular}

Table 4. Calculation of model reliability

\begin{tabular}{|c|c|c|c|c|c|c|}
\hline \multirow{3}{*}{$\begin{array}{c}\text { Latent } \\
\text { Variable }\end{array}$} & \multicolumn{3}{|c|}{ BX Generation } & \multicolumn{3}{|c|}{ YZ Generation } \\
\hline & \multicolumn{2}{|c|}{ Reliability } & \multirow{2}{*}{ Description } & \multicolumn{2}{|c|}{ Reliability } & \multirow{2}{*}{ Description } \\
\hline & $\mathrm{CR} \geq 0.7$ & $\mathrm{VE} \geq 0.5$ & & $\mathrm{CR} \geq 0.7$ & $\mathrm{VE} \geq 0.5$ & \\
\hline Regulation & 0.79 & 0.49 & Reliable & 0.80 & 0.50 & Reliable \\
\hline Lifestyle & 0.86 & 0.54 & Reliable & 0.83 & 0.50 & Reliable \\
\hline Attitude & 0.86 & 0.55 & Reliable & 0.85 & 0.53 & Reliable \\
\hline Search & 0.93 & 0.78 & Reliable & 0.82 & 0.54 & Reliable \\
\hline Action & 0.67 & 0.41 & Reliable & 0.68 & 0.42 & Reliable \\
\hline Share & 0.86 & 0.60 & Reliable & 0.77 & 0.46 & Reliable \\
\hline Overall & 0.97 & $\mathbf{0 . 5 7}$ & Reliable & 0.96 & 0.50 & Reliable \\
\hline
\end{tabular}


Table 5. Hypothesis testing results

\begin{tabular}{cccccc}
\hline Hypotheses & Path & t-value & Direct Effect & Total Effect & t-Valuation \\
\hline \multicolumn{2}{c}{ BX Generation } & & & & \\
\hline H1 & REG $\rightarrow$ AT & 1.87 & 0.13 & 0.13 & Rejected \\
\hline H2 & REG $\rightarrow$ SE & 1.43 & 0.12 & 0.15 & Rejected \\
\hline H3 & REG $\rightarrow$ AC & -1.23 & -0.08 & 0.02 & Rejected \\
\hline H4 & LS $\rightarrow$ AT & 8.99 & 0.79 & 0.79 & Accepted \\
\hline H5 & LS $\rightarrow$ SE & 2.74 & 0.43 & 0.60 & Accepted \\
\hline H6 & LS $\rightarrow$ AC & 3.29 & 0.44 & 0.86 & Accepted \\
\hline H7 & AT $\rightarrow$ SE & 1.34 & 0.21 & 0.21 & Rejected \\
\hline H8 & AT $\rightarrow$ AC & 1.03 & 0.13 & 0.13 & Rejected \\
\hline H9 & SE $\rightarrow$ AC & 6.76 & 0.54 & 0.54 & Accepted \\
\hline H10 & AC $\rightarrow$ SH & 9.07 & 0.89 & 0.89 & Accepted \\
\hline YZ Generation & & & & \\
\hline H1 & REG $\rightarrow$ AT & 2.80 & 0.21 & 0.21 & Accepted \\
\hline H2 & REG $\rightarrow$ SE & -0.24 & -0.02 & 0.05 & Rejected \\
\hline H3 & REG $\rightarrow$ AC & 2.83 & 0.23 & 0.27 & Accepted \\
\hline H4 & LS $\rightarrow$ AT & 7.54 & 0.67 & 0.67 & Accepted \\
\hline H5 & LS $\rightarrow$ SE & 4.86 & 0.57 & 0.78 & Accepted \\
\hline H6 & LS $\rightarrow$ AC & -0.61 & -0.09 & 0.60 & Rejected \\
\hline H7 & AT $\rightarrow$ SE & 2.80 & 0.32 & 0.32 & Accepted \\
\hline H8 & AT $\rightarrow$ AC & 0.10 & 0.01 & 0.01 & Rejected \\
\hline H9 & SE $\rightarrow$ AC & 4.93 & 0.87 & 0.87 & Accepted \\
\hline H10 & AC $\rightarrow$ SH & 7.36 & 0.94 & 0.94 & Accepted \\
\hline & & & & & \\
\hline
\end{tabular}

Moreover Table 5 shows that for $\mathrm{YZ}$ generation, of ten hypotheses, seven hypotheses are accepted. They are H1 (Regulation has a positive effect on Attitude), H3 (Regulation has a positive effect on Action), H4 (Lifestyle has a positive effect on Attitude), H5 (Lifestyle has a positive effect on Search), H7 (Attitude has a positive effect on Search), H9 (Search has a positive effect on Action) and H10 (Action has a positive effect on Share). Three hypotheses are rejected. They are H2 (Regulation has a positive effect on Search), H6 (Lifestyle has a positive effect on Action), H8 (Attitude has a positive effect on Action).

\subsection{Discussion}

The above results show that for BX generation, Regulation variable does not significantly influence Attitude, Search and Action. The direct effect of Regulation to Attitude, Search and Action is only $0.13,0.12$ and -0.02 respectively. Moreover the total effect of Regulation to Action is only 0.02. It means that for BX generation, there is no adequate government regulation and program that has encouraged them to consume more coffee. This generation possibly feels that if there are regulations and programs regarding coffee consumption, the regulations and programs are not for them or not enough to encourage them to consume the coffee. For this generation, coffee consumption is more influenced by their lifestyles rather than by regulation.

Moreover, the results confirm several previous studies that there is a relationship between lifestyles and consumer behavior. For BX generation, Lifestyle significantly and strongly influences Attitude, Search and Action behavior of the consumer, with the total effect of 0.86 . Lifestyle also has a strong direct effect to the attitude as shown by the effect of 0.76 . Lifestyle also influences directly to the action as shown by the effect of 0.44 . Lifestyle influences all aspects of consumption behavior, including Attitude, Search and Action.

For BX generation, there is no significant effect of Attitude on Search and Action, however the load of the effect of Attitude on Search is high enough, i.e. 0.21. Whereas the effect of Attitude to Action is only 0.16. It means that Attitude generally influences Search. Moreover, Search significantly influences Action, and Action influences Share.

For YZ generation, the effect of regulation is different from the effect of regulation for BX generation. For YZ generation, Regulation significantly influences the Attitude with the direct effect of 0.21. Likewise Regulation also significantly influences Action with the direct effect of 0.24 and total effect of 0.27. This fact implies that YZ generation might feel that they are benefited by the government regulation. Or it is possible that the young generation is relatively more responsive to the government regulation.

Moreover, the influence of Lifestyles to consumer behavior is also significant as showed by t test and loading effects as follows. Lifestyle has significant effect on Attitude and Search with the direct effect of Lifestyle to Attitude and Search is 0.67 and 0.57 . The direct effect of Lifestyle to Action is not significant with the loading factor of only -0.09 . However the total effect of Lifestyle to Action is relatively high with the loading factor of 0.60 .

These results indicate that, in general for YZ generation, Regulation and Lifestyle have positive and significant effects on consumer behavior. Even though H2 is rejected, (meaning the Regulation does not have positive effect on Search), however the total effect of Regulation is relatively still high. Likewise, Lifestyle has a positive effect on coffee consumption behavior with the effect values of Regulation are of $0.67(\mathrm{H} 4)$ and $0.57(\mathrm{H} 5)$. Even though $\mathrm{H} 8$ is rejected, i.e., Lifestyle does not have positive on action, however the total effect of Lifestyle on consumer behavior is still relatively very high.

The difference between BX generation and YZ generation lies in Regulation variable, where in the BX generation, Regulation variable has no effect on coffee consumption behavior. The total effect of Regulation variable to Action behavior is very small, i.e. 0.02. Meanwhile in the YZ generation, Regulation variable has a significant effect on consumer behavior. The total effect of Regulation to Action behavior is relatively high, i.e. 0.27 . 
This finding shows that the Regulation as a stimulus has resulted in difference response on the consumers. In other words, the older generation may feel that government regulations do not pay much attention to their consumption preferences. So whatever the regulations are, even though the government concerns to the young generation, it does not affect the old consumption patterns.

Meanwhile, in the younger generation, government regulations are considered sufficient to pay attention to their interests and preferences. It could be that the emergence of many new cafes, those are loved by young people, is considered as a part of the government's attention to the younger generation of coffee lovers. In addition, it is also possible that the psychology of the young generation which usually more responsive to any stimulus, makes them to also be more responsive to any regulation by government.

Based on the analysis above, it can be seen that there is a similar response between the $\mathrm{BX}$ generation and the $\mathrm{YZ}$ generation due to the influence of Lifestyle variables. The total effect of Lifestyle variables on the consumption behavior of $\mathrm{BX}$ generation is significant and positive, with a loading factor of 0.86. Likewise, the total effect of Lifestyle variable on the consumption behavior of YZ generation is positive and significant, with the value of 0.60 . However, when further compared, it is seen that the $\mathrm{BX}$ generation has a relatively greater influence of Lifestyle than the YZ generation does. This fact proved that the influence of Lifestyle factors to the older generation behavior is relatively greater than to that of the younger generation behavior.

Further observations on the significance test of the Attitude, Search, Action and Share variables show that in general the test results are in line with the proposed hypotheses, namely Attitude affects Search and Action, Search affects Action, and Action affects Share. However, there is a slight difference in the component of the effect of Attitude on Search and Action responses, between $\mathrm{BX}$ and $\mathrm{YZ}$ generations. In the $\mathrm{BX}$ generation, Attitude is relatively not significant in influencing Search and Action. Whereas in the YZ generation, Attitude is relatively not significant in influencing Action, but it significantly influences Search. Moreover, in both BX and YZ generations, Search has a significant effect on Action and Action has a significant effect on Share. Furthermore, when compared, it appears that the effect of Search on the Action variable is 0.54 in the $\mathrm{BX}$ generation, while the effect of Search on the action in the YZ generation is 0.87 . Likewise, the effect of Action on the Share of the BX generation is 0.89 , while the effect of the Action on the YZ generation is 0.94 .

This result confirms the difference in the responses of the two-generation clusters. The effect of Search on Action, and the effect of Action on Share, are relatively higher in the YZ generation than in the BX generation. This finding is in line with the fact presented by Dimock [49] that generation $\mathrm{Z}$ dominates online searches for information in the last few years, and by Zhu et al. [19] that generation Y accesses internet very frequently and seek for information actively. Moreover, it can be resumed that the tendency of young people using information technology tools in consuming coffee is higher than the older generation.

\subsection{Managerial and theoretical implication}

Based on the analysis above, it is obvious that regulation variable has different responses according to the age of the respondents. For young generation coffee consumption resulted in significant consumption behavior. However for the old generation, there is no significant effect of coffee consumption. This means that the $\mathrm{YZ}$ generation feels that the current regulations that encourage coffee consumption are quite favorable to them. On the other hand, the BX generation could have known better about what has been done by the government and feels that the government pays little attention to policies and programs that encourage people to increase their coffee consumption. Therefore, several policies and programs need to be formulated to encourage coffee consumption.

Learning from countries and regions that have succeeded in increasing coffee consumption, such as Brasil, Columbia, Guatemala [39], and because the environment issue is now become concerns of many consumers [70], and in accordance with the research regarding coffee policies in Indonesia [40], the Indonesian Government can develop policies and programs according to the local context, including: (1) Ensuring the coffee to be produced by the industry and consume by people is of high quality, (2) Organizing various expos and events about coffee, which focus on, among others: developing coffee culture through education, consuming local coffee is an important part of a pleasant modern life, promoting local coffee as a world-class sustainable product, (3) Celebrating the coffee harvest season and offering coffee tour packages to visit production centers and the coffee industry.

This research contributes to the existing literature in the following ways. First, the research provides empirical and updated findings for SOR model in combination with AISAS framework in the case of coffee consumption in Indonesia. Second, the study highlights the role of regulation and lifestyle in coffee consumption, which confirms that lifestyle strongly determines the coffee consumption, whereas regulation has different response depending on the consumer generation. In the older generation, coffee consumption is more triggered by their lifestyle rather than by external stimuli. In the younger generation, coffee consumption is influenced not only by lifestyle factors but also influenced by external stimuli. Third, the research confirms that regarding coffee consumption the younger generation is more responsive to external stimuli than the older generation. Or in other words, the older generation tends to be less responsive to external stimuli, which in this case is a regulatory stimulus.

\section{CONCLUSION AND RECOMMENDATION}

Some conclusions of this research are: First, the effects of Regulation to the coffee consumer behavior across generations are different. For the BX generation, the Regulation variable does not have a positive and significant effect on the behavior of coffee drink consumption; while for the $\mathrm{YZ}$ generation, the Regulation variable has a positive and significant effect on the behavior of coffee drink consumption. Second, Lifestyle has a positive and significant influence on coffee consumption behavior for both $\mathrm{BX}$ and $\mathrm{YZ}$ generations. However, the Lifestyle variable in the BX generation has a greater influence on the behavior of coffee drink consumption than in the $\mathrm{YZ}$ generation. Moreover in the older generation, coffee consumption is more triggered by their lifestyle rather than by external stimuli. Third, the combination of the SOR model and the AISAS framework has proven to be able to describe very well the concept of coffee consumption behavior from 
different generations in the recent era. Fourth, both the older and younger generations have a real tendency to seek information using internet (Search) and share their experiences in consuming (Sharing) to other people. However, the younger generation appears to be more intensive in seeking information and more extensive in sharing experiences than the older generation does.

This study has limitations, namely it is still too general in mapping the influences of regulation on coffee consumption and therefore requires a more detailed analysis. Some recommendations therefore could be considered, among others: First, further research needs to be carried out to identify the main factors causing the insignificant regulatory factor for coffee consumption in the BX generation. Second, more research to measure consumption across generation need to be carried out with more stimuli as variables. Third, efforts to increase coffee consumption can be taken according to the local context, among others, through improving the quality of coffee, various promotions and campaigns.

\section{REFERENCES}

[1] [ICO] International Coffee Organization. (2021). World Coffee Consumption. http://www.ico.org/prices/newconsumption-table.pdf. accessed on Feb. 7, 2021.

[2] Indonesia. Central Agency of Statistics. (2016). Consumption Expenditure of Population of Indonesia in 2016. Book I. Results of the National Socio-Economic Survey.

https://www.bps.go.id/publication/2017/11/03/5fe55314 9eeee30055e782ac/pengeluaran-untuk-konsumsipenduduk-indonesia--september-2016.html, accessed on Aug. 30, 2021.

[3] Indonesia. Central Agency of Statistics. (2017). Consumption Expenditure of Population of Indonesia in 2017. Book I. Results of the National Socio-Economic Survey.

https://www.bps.go.id/publication/2018/06/11/b09f7e9a a02a8f39ac02fce0/pengeluaran-untuk-konsumsipenduduk--indonesia--september-2017.html, accessed on Aug. 30, 2021.

[4] Indonesia. Central Agency of Statistics. (2018). Consumption Expenditure of Population of Indonesia in 2018. Book I. Results of the National Socio-Economic Survey.

https://www.bps.go.id/publication/2019/06/28/5353a31 8520b45aa07520076/pengeluaran-untuk-konsumsipenduduk-indonesia--september-2018.html, accessed on Aug. 30, 2021.

[5] Indonesia. Central Agency of Statistics. (2019). Consumption Expenditure of Population of Indonesia in 2019. Book I. Results of the National Socio-Economic Survey.

https://www.bps.go.id/publication/2019/11/01/5b55004 2c562b85f7f9c424c/pengeluaran-untuk-konsumsipenduduk-indonesia--maret-2019.html, accessed on Aug. 30, 2021.

[6] Indonesia. Central Agency of Statistics. (2020). Consumption Expenditure of Population of Indonesia in 2020. Book I. Results of the National Socio-Economic Survey.

https://www.bps.go.id/publication/2020/11/02/2d7c91e 53ab840a301689f34/pengeluaran-untuk-konsumsi- penduduk-indonesia--maret-2020.html, accessed on Aug 30, 2021.

[7] Samoggia, A., Riedel, B. (2018). Coffee consumption and purchasing behavior review: Insights for further research. Appetite, 129: 70-81. http://doi.org/10.1016/j.appet.2018.07.002

[8] Sumarwan, U. (2015). Consumer Behavior: Theory and Its Application in Marketing. Second Edition. Ghalia Indonesia Publisher.

[9] Belk, R.W. (1975). Situational variables and consumer behavior. Journal of Consumer Research, 2(3): 157-164. http://dx.doi.org/10.1086/208627

[10] Hovland, C.I. Weiss, W. (1953). Transmission of information concerning concepts through positive and negative instances. Journal of Experimental Psychology, 45(3): 175-182. https://doi.org/10.1037/h0062351

[11] Mehrabian, A., Russell, J.A. (1974). An Approach to Environmental Psychology. MIT Press. Cambridge. MA.

[12] Chen, Y.L., Huang, T.Z. (2012). Mechanism research of OWOM marketing based on SOR and AISAS. Advanced Materials Research, 403-408: 3329-3333. https://doi.org/10.4028/www.scientific.net/AMR.403408.3329

[13] Goi, M.T., Kalidas, V., Zeeshan, M. (2014). Comparison of Stimulus-Organism-Response framework between international and local retailer. Procedia - Social and Behavioral Sciences, 130: 461-468. https://doi.org/10.1016/j.sbspro.2014.04.054

[14] Yoo, C., Park, J., Macinnis, D.J. (1998). Effects of store characteristics and in-store emotional experiences on store attitude. Journal of Business Research, 42: 253-263. https://doi.org/10.1016/S0148-2963(97)00122-7

[15] Turley, L.W., Milliman, R.E. (2000). Atmospheric effects on shopping behavior: A review of experimental evidence. Journal of Business Research, 49(2): 193-211. http://dx.doi.org/10.1016/S0148-2963(99)00010-7

[16] Vieira, V.A. (2013). Stimuli-organism-response framework: A meta-analytic review in the store environment. Journal of Business Research, 66(9): 14201426. http://doi.org/10.1016/j.jbusres.2012.05.009

[17] Zhu, L., Li, H., Wang, F.K., He, W., Tian, Z. (2020). How online reviews affect purchase intention: A new model based on the stimulus-organism-response (S-O-R) framework. Aslib Journal of Information Management. 72(4): 463-488. https://doi.org/10.1108/ajim-11-20190308

[18] Liu, Y., Luo, X., Cao, Y. (2018). Investigating the influence of online interpersonal interaction on purchase intention based on stimulus-organism-reaction model. Human-centric Computing and Information Sciences, 8: 37. https://doi.org/10.1186/s13673-018-0159-0

[19] Zhu, B., Kowatthanakul, S., Satanasavapak, P. (2020). Generation Y consumer online repurchase intention in Bangkok based on Stimulus-Organism-Response (SOR) model. International Journal of Retail \& Distribution Management, 48(1): 53-69. https://doi.org/10.1108/ijrdm-04-2018-0071

[20] Liu, Y., Li, Q., Edu, T., Jozsa, L., Negricea, I.C. (2020). Mobile shopping platform characteristics as consumer behavior determinants. Asia Pacific Journal of Marketing and Logistics, 32(7): 1565-1587. https://doi.org/10.1108/APJML-05-2019-0308

[21] Rejikumar, G, Ajitha, A.A. (2021). Role of impulsiveness in online purchase completion intentions: 
An empirical study among Indian customers. Journal of Indian Business Research, 13(2): 189-222. https://doi.org/10.1108/JIBR-04-2018-0132

[22] Ural, T., Oypan, O. (2021). Investigation of organic food consumption behavior in the context of s-o-r theory: the case of Antakya-Hatay. Erciyes Üniversitesi İktisadi ve İdari Bilimler Fakültesi Dergisi. Kayseri, 58: 177-196. https://doi.org/10.18070/erciyesiibd.755455

[23] Sugiyama, K., Andree, T. (2011). The Dentsu Way: Secret of Cross Swich Marketing from the World's Most Innovative Advertising Agency. New York: McGrawHill Companies. Inc.

[24] Hewlett, P., Wadsworth, E. (2012). Tea, coffee and associated lifestyle factors. British Food Journal, 114(3): 416-427. http://doi.org/10.1108/00070701211213500

[25] Ave, S.D., Venter, M., Mhlophe. B. (2015). Sensory branding and buying behavior in coffee shops: A study on generation $\mathrm{Y}$. The Retail and Marketing Review, 11(2): 93-110.

[26] Chairy, C. (2017). Factors affecting the intention to consume organic coffee among young people. Jurnal Manajemen, 21(02): 241-254. http://dx.doi.org/10.24912/jm.v21i2.234

[27] Chen, M.F., Lee, C.L. (2015). The impacts of green claims on coffee consumers' purchase intention. British Food Journal, 117(1): 195-209. http://doi.org/10.1108/bfj-07-2013-0196

[28] Lee, K.H., Bonn, M.A., Cho, M. (2015). Consumer motives for purchasing organic coffee: The moderating effects of ethical concern and price sensitivity. International Journal of Contemporary Hospitality Management, 27(6): 1157-1180 http://doi.org/10.1108/IJCHM-02-2014-0060

[29] Lee, G.W.M., Rajaratnam. S.D., Konar, R. (2018). Key attributes of Malaysian specialty coffee shops: An exploratory investigation. Asia-Pacific Journal of Innovation in Hospitality and Tourism (APJIHT), 7(2): 69-83.

[30] Li, J., Streletskaya, N.A., Gomez, M.I. (2019). Does taste sensitivity matter? The effect of coffee sensory tasting information and taste sensitivity on consumer preferences. Food Quality and Preference, 71: 447-451. https://doi.org/10.1016/j.foodqual.2018.08.006

[31] Hashim, N.H., Mamat, N.A., Nasarudin, N., Halim N.A.A. (2017). Coffee culture among generation Y. Pertanika Journals of Social Science \& Humanities, 25(S): 39-48.

[32] Ting, H., Thurasamy, R. (2016). What matters to infrequent customers: A pragmatic approach to understanding perceived value and intention to revisit trendy coffee café. SpringerPlus 5(1): 1-11. http://doi.org/10.1186/s40064-016-2259-5

[33] Wang, E.S.T., Yu, J.R. (2016). Effect of product attribute beliefs of ready-to-drink coffee beverages on consumerperceived value and repurchase intention. British Food Journal, $\quad 118(12)$ : 2963-2980. http://doi.org/10.1108/BFJ-03-2016-0128

[34] Aguirre, J. (2016). Culture, health, gender and coffee drinking: A Costa Rican perspective. British Food Journal, 118(1): 150-163. http://doi.org/10.1108/BFJ-082015-0298

[35] Kim, S.H., Lee, S. (Ally). (2017). Promoting customers' involvement with service brands: evidence from coffee shop customers. Journal of Services Marketing, 31(7):
733-744. http://doi.org/10.1108/jsm-03-2016-0133

[36] Suhud, U., Puter, C.D., Wibowo, S.F. (2017). Measuring brand loyalty of coffee shop visitors in Jakarta. Asean Marketing Journal, $\quad 9(1)$ : 28-39. http://doi.org/10.21002/AMJ.V9I1.8902

[37] Sinniah, S., Perumal, G., Seniasamy, R., Das, P.A.M., Mohamed, R.K.M.H., Dhananjaya, O.S. (2018). Experiential quality among coffee lovers: An empirical study in the Malaysian coffee outlets industry. Journal of Social Sciences and Humanities, 15(4): 104-116.

[38] [ITC] International Trade Center. (2021). The markets for coffee-The importance of coffee promotion. https://www.intracen.org/coffee-guide/the-markets-forcoffee/The-importance-of-coffee-promotion, accessed on June 1, 2021.

[39] Kanniah, J.C. (2020). The Importance of Growing Consumption in Producing Countries. Perfect Daily Grind Ltd. https://perfectdailygrind.com/2020/03/theimportance-of-growing-consumption-in-producingcountries, accessed on July 11, 2021.

[40] Andoko, E., Zmudczynska, E., Liu, W. (2020). A strategy review of the coffee policies and development by the Indonesian government. FFTC. Agricultural Policy Platform. https://ap.fftc.org.tw/article/1874. accessed on July 11, 2021.

[41] Basha, M.B., Mason, C., Shamsudin, M.F., Hussain, H.I., Salem, M.A. (2015). Consumers attitude towards organic food. Procedia Economics and Finance, 31: 444-452. http://doi.org/10.1016/S22125671(15)01219-8

[42] Kouy, S., Sangkumchaliang, P., Aditto, S. (2016). Consumers' attitude and intention to purchase organic goods in Cambodia. International Journal of Business, 21(4): 328-341.

[43] Tremblay, A., Panahi, S. (2017). Yogurt consumption as a signature of a healthy diet and lifestyle. The Journal of Nutrition, $147($ Suppl): $1476 S-1480 S$. https://doi.org/10.3945/jn.116.245522

[44] Tangsupwattana, W., Liu, X. (2017). Symbolic consumption and Generation Y consumers: Evidence from Thailand. Asia Pacific Journal of Marketing and Logistics, 29(5): 917-932. http://doi.org/10.1108/apjml01-2017-0013

[45] Najib, M., Sumarwan, U., Septiani, S., Fahma, F. (2021). Application of SWOT-AHP to develop organic food marketing strategy. Academy of Strategic Management Journal, 20(1): 1-8.

[46] Wang, I.M., Hsiao, J., Shieh, C.J. (2005). Study of consumers' purchase behaviors for canned coffee. Journal of Information and Optimization Sciences, 26(2): 385-400. http://doi.org/10.1080/02522667.2005.10699656

[47] Zahra, D.R., Anoraga, P. (2021). The influence of lifestyle, financial literacy, and social demographics on consumptive behavior. Journal of Asian Finance, Economics and Business, 8(2): 1033-1041. http://doi.org/10.13106/jafeb.2021.vol8.no2.1033

[48] Oblinger, D.G., Oblinger, J.L. (2005). Educating the Net Generation. Educause Transforming Education. https://www.educause.edu/ir/library/PDF/pub7101.pdf.

[49] Dimock, M. (2019). Where millennials end and generation $\mathrm{Z}$ begins. https://www.pewresearch.org/facttank/2019/01/17/wher e-millennials-end-and-generation-z-begins, accessed on July 11, 2021. 
[50] Susanto, V., Amir, M.A.M., Haqqi, M.A.H., Ekomadyo, A.S., Riska, A.S. (2020). The influence of Millenial lifestyle on cafe architecture design. Journal of Architecture, Building \& Environment, 9(2): 69-80.

[51] Falkner, L. (2020). An Exploratory Study of Generational Coffee Preferences. Honors College Theses. Murray State University. https://digitalcommons.murraystate.edu/honorstheses/50.

[52] Howe, N., Strauss, W. (2000). Millennials Rising: The Next Generations. New York: Vintage eBooks.

[53] Harris, K.J., Stiles, J., Durocher, J. (2011). A preliminary evaluation of the millennial shopping experience: preferences and plateaus. Florida International University. Hospitality Review Journal, 29(1): 24.

[54] Solomon, M. (2014). 2015 Is the Year of the Millennial Customer: 5 Key Traits These 80 Million Consumers Share.

https://www.forbes.com/sites/micahsolomon/2014/12/2 9/5-traits-that-define-the-80-million-millennialcustomers-comingyour-way/\#74529cda25e5, accessed on July 11, 2021.

[55] Segokgo, K.T. (2016). The impact of fast food marketing on millennials. Theses and Dissertations. University of Arkansas, Fayetteville. http://scholarworks.uark.edu/ etd/1731.

[56] Abdurrahim, M.S., Najib, M., Djohar, S. (2019). Development of AISAS model to see the effect of tourism destination in social media. Journal of Applied Management (JAM), 17(1): 133-143. http://dx.doi.org/10.21776/ub.jam.2019.017.01.15

[57] Iskandar, J., Najib, M., Yusuf A.M. (2020). Analysis of the effect of the AISAS model (attention, interest, search, action \& share) on sharia finance literacy level (case study on instagram followers of sharia banking). Islamic Banking, 5: 33-53. https://doi.org/10.36908/isbank.v5i2.114

[58] Utama, A.P., Sumarwan, U., Suroso, A.I., Najib, M. (2021). Influences of product attributes and lifestyles on consumer behavior: A case study of coffee consumption in Indonesia. Journal of Asian Finance, Economics and Business 8(5): 0939-0950. https://doi.org/10.13106/jafeb.2021.vol8.no5.0939

[59] Najib, M., Fahma, F. (2020). Investigating the adoption of digital payment system through an extended technology acceptance model: An insight from the
Indonesian small and medium enterprises. International Journal on Advanced Science, Engineering and Information Technology, 10(4): 1702-1708. https://doi.org/10.18517/ijaseit.10.4.11616

[60] Malhotra, N.K. (2010). Marketing Research, An Applied Orientation (6th ed.). London: Pearson Education, Inc.

[61] Nurlaela, S., Sumarwan, U., Najib, M. (2019). Determinants of online journey and its influence on online customer satisfaction associated with online customer loyalty. International Journal of Electronic Marketing and Retailing, 10(3): 230-243. https://doi.org/10.1504/IJEMR.2019.100699

[62] Hair, J.F., Black, W.C., Babin, B.J., Anderson, R.E. (2014). Multivariate Data Analysis ( $7^{\text {th }}$ ed.). London: Pearson Education Limited.

[63] Scientific Software International. (2021). LISREL. https://ssicentral.com/index.php/products/lisrel/, accessed on October 1, 2021.

[64] Hasan, J. (2012). Development of models for increasing interest in buying environmentally friendly products: A perspective of innovation diffusion theory. Bogor, Indonesia: Unpublished Doctoral dissertation, Postgraduate School. Bogor Agricultural University.

[65] Hawkins, D.I., Mothersbaugh, D.L. (2010). Consumer Behavior: Building Marketing Strategy (11 ${ }^{\text {th }}$ ed.). New York: McGraw-Hill Irwin.

[66] Kotler, P., Keller, K.L. (2016). Marketing Management (15 ${ }^{\text {th }}$ ed). London: Pearson Education Limited.

[67] Adawiyah, R., Najib, M., Ali, M.M. (2021). Information effect on organic vegetable purchase interest through consumer preferences and awareness. Journal of Asian Finance, Economics and Business, 8(2): 1055-1062. http://doi.org/10.13106/jafeb.2021.vol8.no2.1055

[68] Tabachnik, B.G., Fidell, L.S. (2013). Using Multivariate Statistics. Sixth Edition. London: Pearson Education Inc.

[69] Kline, R.B. (2016). Principles and Practice of Structural Equation Modeling ( $4^{\text {th }}$ ed.). New York: The Guilford Press.

[70] Ahmed, M.A., Arshad, A., Anwar ul Haq, M., Akram, B. (2020). Role of environmentalism in the development of green purchase intentions: A moderating role of green product knowledge. International Journal of Sustainable Development and Planning, 15(7): 1101-1111. https://doi.org/10.18280/ijsdp.150714 